\title{
The Impact of Unilateral Divorce on Crime
}

\author{
Julio Cáceres-Delpiano \\ Universidad Carlos III de Madrid
}

\author{
Eugenio Giolito \\ ILADES-Universidad Alberto Hurtado, Chile \\ and IZA
}

Accepted for publication by The Journal of Labor Economics on July 29, 2011

\begin{abstract}
Using data from the FBI's Uniform Crime Report program and differences in the timing of the reform's introduction, we find that unilateral divorce caused an increase in violent crime rates of approximately 9 percent during the period 1965-1996. When we use age at the time of the reform as an additional source of variation, our findings suggest that young adult cohorts, who were children at the time of the reform, were particularly affected. Finally, we show evidence that a potential channel behind our findings is an increase in poverty and inequality among mothers who were "surprised" by the reform.
\end{abstract}

We are indebted to the editor, Christopher Taber, and to an anonymous referee for their valuable comments. We also thank Dan Black, Antonio Cabrales, Irma Clots, Nezih Guner, Matilde Machado, Ricardo Mora and Seth Sanders for their helpful suggestions. Financial support from the Spanish Ministry of Education (Grants BEC2006-05710 and ECO2009-11165). Giolito thanks Duke University for their hospitality and financial support. Errors are ours. Contact the corresponding author, Julio Caceres-Delpiano, at jcaceres@eco.uc3m.es. 


\section{Introduction}

Family as institution has undergone a "complete make-over" in the U.S. and Europe over the last fifty years. Among the most important institutional changes was the reform in divorce legislation, often-called the "Divorce Revolution". Unilateral divorce -the right of one spouse to seek a divorce without the consent of the other- has captured the greatest amount of attention in the literature during the last twenty years. ${ }^{1}$ After a lengthy scholarly debate about the impact of unilateral divorce on divorce rates (Peters 1986; Friedberg 1998; Gruber 2004), there is now a growing consensus that there was a short-term increase in divorce rates (around 8-10 years) following the reform (Wolfers, 2006). Scholars suggest that the reform has caused changes in the selection into and out of marriage, increasing the average match-quality of new and surviving marriages (Mechoulan 2006; Matouschek and Rasul 2008). ${ }^{2,3}$

Using U.S. Census data, Gruber (2004) finds that those adults who were exposed to the reform as children have lower educational attainments and lower family incomes. ${ }^{4}$ Although seemingly contradictory, these results are consistent with evidence that the increase in divorce was only temporary and that better marriage selection occurred because of unilateral divorce. Since divorce legislation affected the dissolution clause in a marriage contract, the unilateral reform can be seen as a retroactive change in this clause, affecting those marriages already in place at the time of the reform. Therefore, a change in legislation may have produced heterogeneous effects on those people who decided to marry, had children or made marriage investments based on the previous divorce rules. Hence, while there may have been a transition period with no long lasting consequences at the

\footnotetext{
${ }^{1}$ Nevertheless, the process began before 1950 in a number of states, by removing fault grounds, such as adultery, desertion or physical abuse, in order for spouses to ask for a divorce (Gruber 2004). In the early 1970's some states started introducing not only no-fault grounds in the legislation but also allowing one spouse to ask for a divorce without the consent of the other spouse, which has been called "Unilateral divorce". An additional aspect of the reform is related to the division of property and assets in case of divorce. For a detailed review of the characteristics of the reform, see Mechoulan (2005).

${ }^{2}$ This interpretation gains support from recent evidence on the lower divorce rate among couples married under unilateral divorce, compared with those married under mutual consent (Mechoulan 2006). Additionally, evidence supports a reduction in the average duration of marriages that end in divorce (Matouschek and Rasul 2008).

${ }^{3}$ Recent research has focused on the role of the reform in several other aspects of individual behavior. Some examples are studies on family formation (Drewianka 2004; Alesina and Giuliano 2007), marriage-specific investments (Stevenson 2007) or female labor supply (Gray1998; Chiappori, Fortin and Lacroix 2002; Stevenson 2008). The evidence in these studies also points towards changes in behavior in those marriages formed under the new legislation.

${ }^{4} \mathrm{He}$ also finds that those individuals tend to marry earlier but separate more often, and have higher odds of suicide. Johnson and Mazingo (2000) using 1990 U.S. Census data examine the amount of time individuals were exposed to unilateral divorce laws as children, finding results consistent with Gruber (2004).
} 
aggregate level, there might be different effects for those families "trapped" in that transition, and particularly for their children. This line of reasoning constitutes the main motivation for the present work.

This paper investigates the impact of unilateral divorce reform on crime. Specifically, we are interested in the long-run impact of the unilateral divorce reform on those adults who were exposed to the change in the legislation as children. One motivation for this question comes from combining Gruber's (2004) findings of lower education attainments under unilateral divorce for children and those of Lochner and Moretti (2004), who find that schooling significantly reduces the probability of incarceration and arrest. ${ }^{5}$

Stevenson and Wolfers (2006) provide a link between unilateral divorce and crime, specifically domestic violence and spousal homicide. ${ }^{6}$ They show that in states that introduced unilateral divorce there is a sizable decline in domestic violence and in the number of women murdered by their partner. Given the nature of the outcomes (use of force), and biological differences in terms of physical strength between genders, this analysis mostly captures the benefit to women who were locked into a bad marriage and who, as a consequence of divorce becoming easier, were able to escape from such a difficult environment. As mentioned earlier, it also points toward a better selection into and out of marriage. ${ }^{7}$

Despite the current evidence of a reduction in intimate crime, in this paper we show that unilateral divorce leads to a sizable increase in aggregate violent crime in adopting states. Second, we find that the impact comes principally from individuals who were young children at the time of the reform, whose families were "surprised" by the change of legislation. Consistent with these findings, we provide evidence suggesting that, in the few years following the reform, mothers in adopting states were more likely to become the head of the household and to fall below the poverty line, especially the less educated ones. Therefore, our results suggest that a potential channel linking

\footnotetext{
${ }^{5}$ Consistent with Gruber's findings, Cáceres-Delpiano and Giolito (2008) find, using U.S. Census data for the years 1960-1980, that children are 16 to 24 percent less likely to be enrolled in a private school, and that those of pre-school age at the time of the reform (age 0-4) are more likely to repeat a grade.

${ }^{6}$ In addition to these two outcomes, they find that unilateral divorce produces an 8-16 percent decline in female suicide.

${ }^{7}$ Using data similar to Stevenson and Wolfers, Dee (2003) finds that unilateral divorce significantly increased the number of husbands killed by their wives. Stevenson and Wolfers do not find an effect on husbands killed. One way to reconcile these results, given Dee's shorter sample period (1968-1978), is that his results may come from marriages formed under mutual consent (and where husbands were willing to divorce under the new legislation). If unilateral divorce implied selection into marriage, those effects may have disappeared once new marriages formed under unilateral divorce were taken into account.
} 
the unilateral reform with the increase in crime might have been the worsening in economic conditions of mothers and the increase in income inequality as unintended consequences of the reform.

In order to perform our study, we exploit two sources of variation and we use three different data sets. The first source of variation comes from differences in the timing of divorce law reforms across the United States. Using crime rates from the FBI's Uniform Crime Report program (UCR) for the period 1965-1996, we find that unilateral divorce has a positive impact on violent crime rates, an approximately 9 percent average increase for the period under consideration. Then, using UCR Arrest data, we find, for the overall period under analysis, an average increase of 19 percent in the violent arrest rates, and an approximately 25 percent increase in the case of aggravated assault and murder arrest rates. Across the different specifications, we find that the effects are concentrated mostly in the short to medium-term.

In order to identify more precisely the mechanisms behind our findings, we construct agespecific arrest rates and use a second source of variation — when different cohorts were first exposed to the reform. We find that the cohorts most affected are those who were children at the time of the reform or, in a few cases, born shortly after the change in legislation. We do not find in any case a significant impact for those cohorts who were born more than five years after the reform. The last finding provides additional support for increasing the match quality of new or surviving marriages after the reform. Another robustness check is made by applying similar empirical strategies to individual US Census data, specifically to a sample of men aged 15 to 24 for the period 1960-2000. In this case, our dependent variable, the probability of living in an institution, and our results are in line with those based on crime data.

Finally, we also use Census data for the period 1960-1980 and a sample of mothers with children younger than 18 to analyze the possible underlying mechanisms behind our results. We find that, under unilateral divorce, there is a $7 \%$ increase in the likelihood of becoming the head of the household and a $6 \%$ increase in the probability of falling below the poverty line. When splitting the sample by education of the mother, we observe that both results come entirely from mothers with at most a high school education. Moreover, and in line with our previous results, we find that the most affected are those mothers whose youngest child was already born at the time of the reform.

The paper is organized as follows. In Section 2, we briefly review the related literature. Section 3 describes our empirical strategy and the data sources used in the analysis. In Section 4 we 
present our results for the two specifications described above, and in Section 5 we provide supporting evidence on the impact of the reform on children. Section 6 concludes.

\section{Unilateral Divorce, Family Disruption and Crime}

There is now a wide consensus in the literature that unilateral divorce reform produced an increase in divorce rates in adopting states at least during the first 8-10 years after the change in the legislation (Wolfers 2006). In this paper, we argue that such a temporary increase in divorce was enough to produce a sizable impact on violent crime.

Even though there is extensive literature that has linked family disruption with factors related to crime, in many cases, it is difficult to distinguish correlation from causation. For example, it is a well-known fact that single-headed households, and especially those of young black mothers, are concentrated in disadvantaged neighborhoods with higher crime rates and poverty, low rates of employment and poor educational facilities (Wilson 1987), with all these factors being positively related to engagement in a criminal career.

Despite the fact that the literature devoted to disentangling the causal relationship between single headed families and crime is still not very extensive, there are a few exceptions. Kelly (2000), using data from U.S. metropolitan counties in 1991, finds very different patterns of behavior between property and violent crime ${ }^{8}$. His first finding reveals that, controlling for poverty and inequality, both types of crime are positively influenced by the percentage of female-headed families, but violent crime is much more sensitive (with an elasticity of 1.6 versus 0.7 for property crime). A second major finding in Kelly (2000) is that, while property crime is largely unaffected by inequality but significantly influenced by poverty, violent crime is less sensitive to poverty but

\footnotetext{
${ }^{8}$ Kelly's concern about endogeneity is focused on the variable measuring police activity. This last variable is instrumentalized by per capita income, the share of non-police expenditure by local government in total county income, and the percentage of voters that voted against the Democrat candidate in the 1988 presidential election. Additionally, a potential correlation of the rest of the variables considered and the error term, is checked by running all possible specifications that result from the different combinations of the covariates in the model. The impact of income inequality on violent crime is robust across all potential specifications.
} 
strongly affected by inequality. ${ }^{9}$ In general, Kelly's findings are in line with arguments made in the criminology and sociology literature. ${ }^{10}$

Recent literature has addressed the economic impact of divorce on family income. Using longitudinal data from the PSID and a dynamic model with individual fixed effects, Page and Stevens (2004) find that in the year following a divorce, family income falls by 41 percent and family food consumption falls by 18 percent. Six or more years later, the family income of the average child whose parent remains unmarried is 45 percent lower than it would have been if the divorce had not occurred.

Two other studies have tried an instrumental variables approach to study the impact of divorce on family income. Bedard and Deschênes (2005) show that once the negative selection into divorce is accounted for, ever-divorced women live in households with incomes that are on average similar to those of never-divorced women. New evidence supports that a small or even close to zero impact of divorce on mean income hides sizeable effects on the tails of the income distribution. Ananat and Michaels (2008), using the same instrument for divorce used by Bedard and Deschênes (sex of the first-born child), but using a Quantile Treatment Effect methodology, find that divorce widens income distribution. While some women are successful in generating income through child support, welfare, combining households, and increased labor supply after divorce, other mothers are "markedly" unsuccessful. In fact, this effect of divorce on income distribution is particularly important when we talk about crime. Their results suggest that the destabilization of first marriages may have caused some of the stagnation in poverty rates of women with children over the last several decades.

In Section 5 below we show, using a sample of mothers from the 1960-1980 census, that the unilateral reform produced an increase in the share of single households and an increase in the number of families below the poverty line, and that those impacts came mainly from a sub-sample of less educated women. Our findings suggest that those families "at risk" were the most affected by the reform, and that an increase of income inequality and the share of single low-income households is a potential driving force behind the increase of violent crime, which is consistent with the findings of Kelly (2000).

\footnotetext{
${ }^{9}$ Fajnzylber, Lederman and Loayza (2002) find similar results in a cross-country analysis.

${ }^{10}$ Those factors are, among others, family structure (Matsueda and Heimer 1987; Sampson 1987; Sampson, Laub and Wimer 2006), poverty and inequality (Blau and Blau, 1982; Wilson 1987) and school completion (Rand 1987).
} 
Finally, another channel that might play a role in the relationship between divorce and crime is the fact that children who have been through parental divorce are more likely to live in a household where their mother is working, and therefore receive less supervision. ${ }^{11}$ Regarding this issue, in a recent paper, Stevenson (2008) finds that independent of the laws governing the division of property, unilateral reform produced an increase in female labor participation. ${ }^{12}$

\section{Empirical Strategy, Data and Variables}

We use two different sources of variation to identify the impact of the reform in crime, and the potential channels behind that impact. In the first part of our analysis, we use a "Differences in Differences" approach by using the variation resulting from the differences in the timing of the adoption of unilateral divorce laws across the adopting states, and the fact that other states did not pass this reform to estimate the effects of these laws on aggregate crime and arrest rates. We also include a dynamic specification, allowing the impact to vary by time since the reform was introduced, in order to differentiate short run from long run impacts of the reform (Wolfers, 2006). The following expression represents the first specification of interest:

$$
\mathrm{y}_{\mathrm{st}}=\propto_{\mathrm{s}}+\beta_{\mathrm{t}}+\delta \mathrm{Z}_{\mathrm{st}}+\gamma \mathrm{U}_{\mathrm{st}}+\varepsilon_{\mathrm{st}}
$$

where $\mathrm{y}_{\text {st }}$ represents the natural logarithm of an specific crime rate for state $\mathrm{s}$ at time $\mathrm{t}$, $\propto_{\mathrm{s}}$ and $\beta_{\mathrm{t}}$ state and year fixed effects, respectively, and $\mathrm{Z}_{\mathrm{st}}$ stands for time-varying state demographic, aggregate and policy state variables. The variable of interest is $U_{s t}$ which is a dummy variable that takes a value of one for a state " $s$ " that had already adopted the unilateral at year " $t$ ".

As we already pointed out, the timing of the impact is informative about the channel and individuals affected by the reform. With this idea in mind, we introduce a second specification. That is,

\footnotetext{
${ }^{11}$ Paxson and Waldfogel (2002) present evidence that labor force participation has been linked to child maltreatment.

${ }^{12}$ In an earlier work, Gray (1998) finds that the impact of unilateral divorce on female employment critically depends on laws governing property division.
} 


$$
\mathrm{y}_{\mathrm{st}}=\propto_{\mathrm{s}}+\beta_{\mathrm{t}}+\delta \mathrm{Z}_{\mathrm{st}}+\sum_{\mathrm{c}} \gamma^{\mathrm{c}} \mathrm{U}_{\mathrm{st}}^{\mathrm{c}}+\varepsilon_{\mathrm{st}}
$$

Here the variable of interest is $U^{c}$ st, which represents a series of dummy variables that take a value of one for those states that have adopted the unilateral reform after "c" years (Wolfers, 2006).

In the second part of our study, we use an additional source of variation, coming from the age at which a particular cohort faced the unilateral reform. This second source of variation allows us to identify differential effects between individuals that have faced the reform at different points in their lives. Since the source of variation in this case is at the state-age-year level, we are also able to control for confounding factors that might operate at the state-year, state-age or age-year level. ${ }^{13}$ Specifically, we estimate the following equation,

$$
\mathrm{y}_{\mathrm{ast}}=\theta_{\mathrm{st}}+\mu_{\mathrm{at}}+\eta_{\mathrm{sa}}+\operatorname{legal}_{\mathrm{ast}}+\sum_{\mathrm{j}} \gamma^{\mathrm{j}} \mathrm{U}_{\mathrm{st}} * 1\left\{\mathrm{a}_{\mathrm{j}} \leq\left[\mathrm{t}-\mathrm{a}-\mathrm{YUni}_{\mathrm{s}}\right] \leq \mathrm{b}_{\mathrm{j}}\right\}+\varepsilon_{\mathrm{ast}}
$$

In this second specification, $\mathrm{y}_{\text {ast }}$ represents a crime rate for a cohort of age a, living in state $\mathrm{s}$ in year t. Here $\theta_{\mathrm{st}}, \mu_{\mathrm{at}}$ and $\eta_{\mathrm{sa}}$ represent state,-year, age-year and state-age interactions, respectively. Furthermore, legal ${ }_{\text {ast }}$ is a dummy variable representing whether abortion was already legal in state $\mathrm{s}$ in the year of birth of that cohort. ${ }^{14}$ In this case, $\mathrm{U}_{\mathrm{st}}$ is a dummy variable that indicates that unilateral divorce was already legalized in state $s$ in year $t ; 1\{\}$ is an indicator function that takes a value of one when the logic statement \{\} is true, and zero otherwise, and $\mathrm{YUni}_{\mathrm{s}}$ is the year of adoption of unilateral divorce in the state $s$. Specifically, the expression $\left[\mathrm{t}-\mathrm{a}-\mathrm{YUni}_{\mathrm{s}}\right]$ represents either the age at the time of introduction of the reform (if negative), or the number of years the reform was in place when that cohort was born (if positive). The parameter of interest, $\gamma^{j}$, can be interpreted as the ceteris paribus impact of unilateral divorce on those cohorts of ages in the range $\left[a_{j}, b_{j}\right]$ at the time of the reform, compared to those individuals living in states that have not

\footnotetext{
${ }^{13}$ One example of these factors are the temporary state-specific crime waves due to the introduction of new, illicit drugs, like crack cocaine (Donohue and Levitt, 2001, 2004, 2006; Joyce, 2004, Foote and Goetz, 2008). For a detailed description of the crack epidemic, see Fryer et al. (2005).

${ }^{14}$ A closely related work in terms of the outcomes studied here is Donohue and Levitt (2001), who link the legalization of abortion in the early 1970's with the drop in the crime rate in the 1990's. Even though here we focus on a different question, we try to take into account several issues raised in the empirical debate over Donohue and Levitt's original work. See Joyce, 2004 and 2009; Foote and Goetz 2008; Donohue and Levitt, 2004 and 2006 for details.
} 
adopted unilateral divorce $\left(\mathrm{U}_{\mathrm{st}}=0\right)$. Seven age groups at the time of the introduction of unilateral divorce are defined: Born 6 or more years after the reform, born 1 to 5 years after the reform, age between 0 and 3 at the time of the reform, between 4 and 7, 8 and 11 and so on. In this specification, there are three sources of variation of the variable associated to the parameter $\gamma^{\mathrm{j}}$. In addition to the differences in the timing of adoption of unilateral divorce and the fact that not all states have introduced it, it also considers the fact that the reform affected people at different points in their lives.

Except for the case of individual Census data, in this paper we perform unweighted OLS regressions. ${ }^{15}$ Finally, to control for serial correlation, we correct the standard errors by clustering by state, following Bertrand, Duflo, and Mullainathan (2004).

\section{Data and Variables}

The crime data in our analysis comes from the FBI's Uniform Crime Report program (UCR) (crime rates and arrest data sets). We complement these data sets by using PUMS U.S. Census data for the period 1960-2000 to study the impact on the likelihood of being institutionalized. Finally, in Section 5, devoted to discussing some of the channels behind our results, we show the impact of unilateral divorce on different outcomes using a sample of mothers from the 1960-1980 PUMS U.S. Census.

The UCR data consists of information at the state level for the eight types of crimes that are considered most important because of their nature or volume among all offenses (Part I offenses). These felonies are classified into two groups: Violent Crime ${ }^{16}$ and Property Crime. Violent crime includes murder and non-negligent manslaughter, forcible rape, robbery, and aggravated assault. Property Crime includes burglary, larceny-theft, motor vehicle theft, and arson.

\footnotetext{
${ }^{15}$ We get similar conclusions for state population weighted regressions (Caceres-Delpiano and Giolito 2008b). For an analysis on the potential problems of using WLS instead of OLS in differences-in-differences dynamic specifications, applied particularly to the case of unilateral divorce, see Lee and Solon (2011).

${ }^{16}$ The Uniform Crime Reporting (UCR) Program defines as violent crimes those that involve force or threat of force. The classification of these offenses is based on police investigation as opposed to the determination of a court, medical examiner, coroner, jury, or other judicial body. For more details, see the Uniform Crime Reporting codebook at http://www.fbi.gov/ucr/handbook/ucrhandbook04.pdf.
} 
In this paper, we use, first, the crime rates reported at state-year level for the period 1965$1996,{ }^{17}$ and data on the number of arrests by type of offense. Each year, police agencies in metropolitan statistical areas in the United States, report the total number of arrests to the FBI UCR Program, which are disaggregated by age, sex, and race. ${ }^{18}$ The age detail is at single age for 15 to 24 year-olds and grouped for the other ages. ${ }^{19}$ This level of detail is useful since it allows us to identify the population affected by the reform, which is helpful for the analysis of the potential channels.

A second data source consists of a sample of men whose age is between 15 and 24 and constructed from the U.S. Census PUMS for the period 1960- 2000. US Census samples provide information about group quarters. We use this information to construct a dummy variable that takes a value equal to one if the individual lives in an institution, and zero otherwise.

Because the FBI data rely on police reporting, there are often problems of underreporting or downgrading of crimes. However, the use of aggregate information at different levels (state-year, state-year-age or state-year-race), as well as analyzing different types of offenses allow us to draw conclusions based on results that are less sensitive to measurement errors. ${ }^{20}$ Here the use of Census data becomes crucial as a robustness check of the results obtained using the UCR data.

We follow Friedberg's (1998) coding without separation requirements (See Table 1, Column 1). ${ }^{21,22}$ That is, in our analysis, we consider as "adopting states" those 31 states that adopted

\footnotetext{
${ }^{17}$ The UCR data has information for the whole period 1960-2005 with the exception of NY for which the information is available since 1965. Therefore, we restrict the analysis to the period 1965-1996, because for other covariates the information is not available beyond the selected period. Nevertheless, we checked the robustness by estimating a model for the whole period without controls; the results do not change qualitatively.

${ }^{18}$ In order to construct the arrest rates, given the level of disaggregation, we use three different sources of population counts (see the Data Appendix).

${ }^{19}$ During the period 1965-1997, 48 percent of the arrests related to violent crimes affected individuals between 15 and 24 years old.

${ }^{20}$ Stevenson and Wolfers (2006) check the FBI counts of total murders each year by state against murder counts gathered by the National Center for Health Statistics (NCHS). They find that these two data sources provide murder counts that are consistent with each other.

${ }^{21}$ Differently from Friedberg (1998), here we also include Wisconsin as an adopting state, given that separation is voluntary in this state, following Ellman and Lohr (1998), Gruber (2004) and Mechoulan (2005), among others. Friedberg acknowledges that the definition of unilateral divorce is disputable for this state (see Table 1 on Friedberg, 1998).

${ }^{22}$ However, our main results are robust to the inclusion of states that require separation for divorce or (Table 1 , Column 2) or to an alternative coding such as the one from Gruber, 2004 (Table 1, Column 3).
} 
unilateral divorce after 1960, while the remaining 20 states are considered "control states". ${ }^{23,24}$ However, the main results of this paper are robust to the inclusion of states which require separation to grant a divorce (See Table 1, Column 2) ${ }^{25}$, and to an alternative coding from Gruber (2004). (See Table 1, Column 3).

In our different specifications, we use a set of these state-time-varying covariates, which we classify into three different groups: demographic variables include dummies for the fraction of blacks, fraction of immigrants, a quadratic polynomial in state population, and a set of dummies for the state-year age structure. As state aggregate variables, we include the log of state per capita income, the state unemployment rate, the log of the lagged incarcerated population, and a dummy for the introduction of crack in the mid-late $80 \mathrm{~s}^{26}$. Finally, state policy variables include dummies for the consideration of fault for property division and for the existence of norms regarding the equitable division of property in the case of divorce, dummies for abortion accessibility by state and year, ${ }^{27}$ and for the existence of the death penalty.

The comparative evolution between adopting and non-adopting states for raw violent and property crime rates is shown in Figure 1. For each of the panels we introduce two vertical lines signaling the years 1970 and 1975, which indicate the period that most states adopted the unilateral divorce law (see Table 1). We see, first, that adopting states have a lower incidence of violent crimes than non-adopting states. On the other hand, however, adopting states have a higher incidence of property crime for the period under analysis. Second, after (and not before) the unilateral reform started there is a monotonic reduction in the gap between adopting and non-adopting states in violent crime rates, with almost no observable difference in the 1990's. On the other hand, the gap between

\footnotetext{
${ }^{23}$ The states are Alaska, Arkansas, Delaware, District of Columbia, Illinois, Louisiana, Maryland, Mississippi, Missouri, New Jersey, New York, North Carolina, Ohio, Pennsylvania, South Carolina, Tennessee, Utah, Vermont, Virginia, and West Virginia. See Column 2 of Table 1.

${ }^{24}$ According to Gruber (2004), Alaska passed the legislation in 1935, so we will consider it a non-adopting state.

${ }^{25}$ In this case, we consider as adopting states those that adopted the regime in 1968 or later, given the information available.

${ }^{26}$ According to Fryer et al. (2005), crack cocaine use emerged in the mid-1980s, peaking in the early-1990s, before falling slowly thereafter.

${ }^{27}$ Abortion was legalized nationally in 1973 with Roe vs. Wade. Nevertheless, five states (Alaska, California, Hawaii, New York, and Washington) had legalized or quasi-legalized abortion around 1970. Donohue and Levitt (2001) argue that the five states that allowed abortion in 1970 experienced declines in crime rates earlier than the rest of the nation, which legalized in 1973 with Roe v. Wade. However, Joyce (2004) argues that Donohue and Levitt's evidence that crime fell earlier and faster in the early legalizing states may be spurious, a result of the differential timing in the evolution of crack markets.
} 
adopting and non-adopting states in terms of property crime rates seems stable during the period, with a marginal tendency to increase after 1985.

\section{Results}

\subsection{Standard and Dynamic Specifications}

Table 2 presents estimates of the impact of the reform in equation (1), with the natural log of total crime, property crime and violent crime rates as dependent variables. Each column corresponds to a different specification with the latter columns controlling for an increasing number of covariates. The first column presents the basic model ("Basic") including just dummies by year and state as explanatory variables. The second column also includes demographic variables; in Column 3 we add state aggregate variables; in Column 4 policy variables and in Column 5, a linear trend whose impact varies by state. ${ }^{28}$ Additionally, the estimates for each specification and crime rate have been obtained by using three different codings of the unilateral reform, which are presented in horizontal panels: Friedberg without separation requirement (Panel A), Friedberg with separation requirements (Panel B) and Gruber (Panel C). ${ }^{29}$

The results in Table 2 are robust across specifications and codings used for unilateral divorce. For all specifications, we find that unilateral divorce is associated with an increase in the average violent crime rate for the period under analysis. Nevertheless, the results for property and total crime rates (which is strongly related to property crime) depend on the specification and coding used, with an impact that is marginally negative or/and statistically insignificant. Using Friedberg's code (Panel A), the magnitude of the impact on violent crime is approximately 9 percent for the complete period (38 violent crimes per 100,000 people), which is stable across specifications. Using alternative codes for unilateral, we obtain similar conclusions and magnitudes.

Table 3 presents estimates of $\gamma^{e}$ for the dynamic specification described in equation (2) with the natural log of violent crime as a dependent variable. As before, each column corresponds to a different specification with the latter columns controlling for an increasing number of covariates.

\footnotetext{
${ }^{28}$ By including a state specific time trend, we try to prevent the estimated impact of the unilateral reform from capturing pre-existing trends in the selected outcomes.

${ }^{29}$ The details of these three codings are in Columns 1, 2 and 3 of Table 1, respectively.
} 
The results in Table 3 reveal that the unilateral reform's impact unfolds during the eight to twenty years after the change. Nevertheless, beyond that window the impact depends on the specification used. $^{30}$

We check the robustness of the results by analyzing the timing of the change. A causal interpretation of the previous findings would be weakened if we found that crime rates were falling or increasing in adopting states prior to the enactment of unilateral divorce, compared with non-adopting states. In order to examine these issues, we add a series of leads to equation (2), coding dummies for whether the unilateral divorce law would be passed in 1 year, 2 years, and so on. Figure 2 shows the results for this modified specification for the three outcomes in Table 2 and for aggravated assault. A vertical line indicates the year that unilateral reform was passed. First, for the four crime rates, in no case are the coefficients of the dummies indicating the periods prior to the divorce law reform (individually or jointly) statistically distinguishable from zero. Second, looking at the coefficients to the left of the vertical line (before the reform), we find no indication of a pre-existing trend in adopting states. Third, we obtain the same pattern if we include the rest of the covariates used in the analysis, which suggests that our findings are not driven by other covariates included in the model. ${ }^{31}$ In Table 4 we report the estimates of models (1) and (2) for total violent arrest rates (Columns 1 to 3), for aggravated assault arrest rates (Columns 4 to 6), and for murder arrest rates (Columns 7 to 9). For each type of crime, we split the samples between the White and Black sub-samples. The fact that arrest data is also disaggregated by race is useful for studying whether or not our results are driven by a particular group from the population. ${ }^{32,33}$ The first point to note is that, consistent with the 9 percent increase in the total violent crime rate, unilateral reform is associated as well with an increase of approximately 18 percent in the total violent arrest rate. In addition, the dynamic specification (2) reveals that the impact of the reform takes place during the first 20 years after the introduction of the reform but it is statistically insignificant in the long term. For aggregate aggravated assault and murder arrest rates a similar conclusion is obtained: unilateral divorce had a

\footnotetext{
${ }^{30}$ In the online appendix, we break violent crime down into its respective sub-definitions. We find that impact on violent crime is driven mainly by aggravated assaults crimes.

${ }^{31}$ See the previous working paper version (Caceres-Delpiano and Giolito (2008b).

${ }^{32}$ However, this level of disaggregation is only available by age or race. That is, we are unable to identify rates at agerace cell level.

${ }^{33}$ From now on, we use elasticities evaluated at the sample mean instead of using logs due to the high number of zeros in disaggregated arrest rates.
} 
positive impact that unfolds during the first years after the reform. Splitting the samples by race, we observe that the pattern as well as the magnitude of the reform is similar for the race groups. Nevertheless, for murder arrest rates we observe a marginally stronger impact for blacks. ${ }^{34}$

\subsection{Alternative Specification: Age at the time of the Reform}

In this section, we make use of the fact that arrest data can be disaggregated by age to analyze potential cohort heterogeneity in the impact of the reform. We concentrate on age-specific arrests rates for the population aged 15-24, since the Uniform Crime Reports record arrests by single year of age for this group only. ${ }^{35}$ Table 5 and Table 6 present the estimates for violent crime and aggravated assault arrest rates, respectively, which are robust to several specifications. In both tables, Column 4 shows the results for the estimation of the equation (3), controlling for confounding factors that vary at the state-year, state-age or year-age level.

The results reveal that in all cases, the cohorts affected were those born before unilateral was passed. In fact, for those cohorts born six or more years after the reform, the coefficients are not only insignificant but also considerably smaller than for the rest of the age groups. Finally, we observe that people who were between 8 and 15 years-old when the legislation was passed are those who show the largest point estimate for almost all specifications and outcomes. That is, even though some specifications show a significant effect for people who were 16 years old or older, the coefficients are in all cases smaller than the estimates for those who were children between 8 and 15 years old at the time of the reform.

\subsection{Stock of People in Institutions: U.S Census 1960-2000}

In this section, we use a sample of men who are between 15 and 24 years old from the U.S. Census for the period 1960-2000 in order to check the robustness of our previous results. Although census data does not provide information about individual crime history, the information about group quarters helps us to define a proxy variable for the stock of incarcerated people. Therefore, we define as the outcome of interest a dummy variable that takes a value one if a man lives in an

\footnotetext{
${ }^{34}$ In the online appendix, we present the robustness check for aggravated assault and murder arrest rates to different specifications.

${ }^{35}$ In order to construct age-specific arrest rates we rely on the single-age population counts from the U.S. Intercensal County Population Data (see the Data Appendix).
} 
institution and zero otherwise. ${ }^{36}$ We define the individual's exposure to the unilateral reform as well as the state fixed effect in the model by using state of birth. Therefore, in this section we estimate the following variations from equations (2) and (3):

$$
\text { inst }_{\mathrm{ibt}}=\alpha_{\mathrm{b}}+\beta_{\mathrm{t}}+\gamma \mathrm{X}_{\mathrm{ibt}}+\delta \mathrm{Z}_{\mathrm{bt}}+\sum_{\mathrm{c}} \gamma^{\mathrm{c}} \mathrm{U}_{\mathrm{bt}}^{\mathrm{c}}+\varepsilon_{\mathrm{ibt}}
$$

and

$$
\text { inst }_{i b t}=\propto_{b}+\beta_{t}+\gamma X_{i b t}+\delta Z_{b t}+\sum_{c} \gamma^{c} U_{b t}^{c} * 1\left\{a_{j} \leq\left[t-a-Y_{U n i}\right] \leq b_{j}\right\}+\varepsilon_{i b t},
$$

where inst $t_{\text {ibt }}$ is a dummy variable equal to one if the individual $i$, born in state $b$ lives in an institution at time $t, \propto_{b}$ and $\beta_{t}$, represent state of birth and year fixed effects, respectively, $X_{i b t}$ is a vector of individual characteristics and $\mathrm{Z}_{\mathrm{bt}}$ denotes time-varying aggregate and policy state variables.

Table 7 presents the impact of unilateral reform on the probability of living in an institution. Columns 1 to 4 present the impact of the reform using different specifications for the complete sample of men. Columns 5 and 6 report the impact for the sample of black men. The upper panel (Panel A) presents the dynamic impact of the reform, while the lower panel (Panel B) presents the estimates for the specification based on the age at the time of the reform.

The results in panel A for the complete sample of men show that the unilateral reform has a positive impact on the likelihood of living in an institution by increasing by 0.21 percent points the chances of living in an institution during the five years after the reform, up to 0.91 percent points 20 to 24 years after the reform. These magnitudes in relationship to the average sample mean for the period (1.52\%) correspond to an increase of approximately 13 to 60 percent in the likelihood of living in an institution. The results in panel A also show that the impact is not lasting after 25 years of the reform except for the sample of black men for whom the impact is considerably stronger.

The results in panel B for the complete sample confirm our previous findings. The impact of unilateral reform comes from the individuals that were already born at the time of the reform or born shortly after the change of legislation.

\footnotetext{
${ }^{36}$ Unfortunately, after the 1980 Census it is impossible to distinguish if individuals live in a correctional institution or in another type of facility (mental institution or institutions for the elderly, handicapped or poor).
} 


\section{Impact of the Reform on Related Factors. Mothers 1960-1980 Census}

In this section, we provide evidence of the impact of unilateral divorce on some of the factors that have been linked to crime (see Section 2 por encima de) and for which we have information for the period under consideration. Specifically we analyze the impact on four outcomes characterizing family arrangements and economic outcomes. Our primary data source is the U.S. Census for the period 1960-1980. The sample under analysis consists of mothers 25 to 50 years old, with at least one child under 18 at home. ${ }^{37}$ The first two variables used in the analysis are associated with marital instability: "Currently divorced" is a dummy variable that takes a value of one if a mother's marital status is divorced, and zero otherwise; "Household head" is a dummy variable that takes a value of one if the mother is the head of the household and there is not a husband present, and zero otherwise.

The third variable in the analysis is "Real Family Income" (log). Finally, we use the dummy variable "Poverty" that takes a value of one if the mother falls below the poverty line, and zero otherwise. The first specification of interest is:

$$
\mathrm{y}_{\mathrm{ist}}=\alpha_{\mathrm{s}}+\beta_{\mathrm{t}}+\gamma \mathrm{X}_{\mathrm{ist}}+\delta \mathrm{Z}_{\mathrm{st}}+\theta \mathrm{U}_{\mathrm{st}-1}+\varepsilon_{\mathrm{ist}}
$$

Here $y_{\text {ist }}$ represents a specific outcome for individual i, living in state $s$ at time $t, \alpha_{s}$ and $\eta_{t}$, represent state and year fixed effects. Additionally, $\mathrm{X}_{\mathrm{ist}}$ is a vector of individual characteristics: age, race and education of the mother, and age of the youngest child. Finally, $\mathrm{Z}_{\mathrm{st}}$ denotes time-varying aggregate and policy state variables. ${ }^{38}$ The variable of interest is $U_{\text {st-1 }}$, which is a dummy variable that takes a value of one for those states that had already adopted the unilateral reform the year before the census year. To determine potential heterogeneity in the group of women affected, Table 8 shows the results for the whole sample and for two subsamples depending on the education of the mother.

In the first row of Table 8, we find that unilateral divorce increases the probability of the mother being currently divorced by $18.61 \%$. When we split the sample by education, we observe

\footnotetext{
${ }^{37}$ Recall that we found an impact on crime for people aged 15-24, specifically for the late 80's and early 90's.

${ }^{38}$ State Aggregate variables include the log of personal income per capita, fractions of blacks, age composition of the population, dummies for equitable division of property upon divorce, separation requirements for unilateral divorce and the consideration of fault in property division.
} 
that the impact is remarkably higher for lower educated women (a 20.97\% increase versus $12.41 \%$ for women with at least some college education).

In the second row, we show that unilateral divorce increases the probability that a mother becomes the head of the household by $7.1 \%$ both for the whole sample and for women with at most a high school education. Nevertheless, for higher educated mothers this impact is lower and insignificant. A back of the envelope calculation, using Kelly (2000) elasticity (1.6 for violent crime), suggests that the unilateral reform would imply an $11 \%$ increase in violent crime through an increase of the share of single households of low educated women, which is in line with our findings from previous sections $(9 \%)$.

The results for income also show heterogeneity across mother's education. Even though the coefficient for family income is only statistically significant at $10 \%$, the results appear to be driven by lower educated women despite the lack of power of the coefficients. We also find a $6 \%$ increase in the probability that mothers fall below the poverty line, with this result being entirely driven by the sub-sample of women with lower education. These findings suggest a negative impact of unilateral divorce on the lower tail of the income distribution, which is consistent with the results in Ananat and Michaels (2008) and therefore in the context of Kelly's (2000) findings regarding a causal relationship between inequality and violent crime.

Finally, to find out which cohorts of children were more affected by the reform, we apply a similar specification to the one in equation (3), in this case to individual census data

$$
y_{i s t}=\alpha_{s}+\beta_{t}+\gamma X_{i s t}+\delta Z_{s t}+\sum_{j} \gamma^{j} U_{s t} *\left\{a_{j} \leq\left[t-a-Y U n i_{s}\right] \leq b_{j}\right\}+\varepsilon_{i s t} \text {, }
$$

In this case "a" represents the age of her youngest child, and therefore $[\mathrm{t}-\mathrm{a}]$ indicates the child's year of birth.

Table 9 displays the results of specification (7) for the four outcomes considered in this section. Observe that, except in the case of poverty, which shows a marginally significant impact for children born 1 to 5 years after the reform, all other positive impacts are for families whose "youngest" child was already born at the time of the reform. Notice that, in the case of a divorced or head of household mother, we find significant negative impacts for children born more than 5 years after the reform. These results suggest that a specific group of mothers, those whose youngest child was born before the unilateral reform was passed, are more likely to be a single household head, have lower family incomes and be below the poverty line. Comparing the last results with those in 
Tables 4 to 6 (Arrest rates) and 7 (Institutions-Census data), it is easy to see that their youngest children belong to the same cohorts that, years later, become more likely to be arrested or institutionalized.

\section{Conclusion}

In this paper, we study the impact of unilateral divorce on crime. Previous research has suggested that divorce laws affected marriage selection and produced some negative effects on individuals who experienced the reform as children. Here we study whether those changes affected crime and arrest rates in states that passed unilateral divorce laws.

First, using data from the FBI's Uniform Crime Report program for the period 1965-1996 and differences in the timing in the introduction of the reform we find that unilateral divorce has a positive impact on violent crime rates, with a $9 \%$ average increase for the period under consideration. Applying a similar specification to arrest data confirms our previous results, with an increase of around $18 \%$ for violent crime arrest rates. In both cases, a dynamic specification tells us that the impact is mostly concentrated between eight and fifteen years after the reform. Consistent with these results, by using Census data for 1960-2000 we find that unilateral divorce is associated with an increase in the fraction of institutionalized people. In this case, the geographic source of variation is established at the state of birth level, which gives us another robustness check to our results since our hypothesis is that the mechanism affects the individuals when they are children.

We then use the age at the reform as the second source of variation. We are not only able to confirm the positive effect on different types of violent arrests rates, but we also find an impact for property crimes. The results confirm that the impact comes mostly from cohorts who were already born at the time of the reform. Our results on violent crime and aggravated assault are robust to a specification that controls for all confounding factors that may have been operating at the state-year, state-age or age-year-level.

Finally, we provide supporting evidence about some potential mechanisms underlying our results on crime. Using a sample of mothers from the U.S. Census for the period 1960-1980, we find that low educated mothers were more likely to become the head of the household and to fall below the poverty line. Therefore, our results suggest that a potential channel linking the unilateral reform 
with the increase in crime might have been the worsening in economic conditions of mothers and the increase in income inequality as unintended consequences of the reform. 


\section{Data Appendix}

\section{Aggregate Crime and Arrest Data}

Aggregate crime and arrest data used in the analysis are from the FBI's Uniform Crime Report program (UCR) for the period 1965-1996. The UCR data has information for the whole period 19602005 with the exception of New York (since 1965). The data on crime rates is available from the Bureau of Justice Statistics web page:

http://bjsdata.ojp.usdoj.gov/dataonline/Search/Crime/State/StatebyState.cfm Arrest data is from Chilton and Weber (2000), available from the Inter-University Consortium for Political and Social Research (ICPSR) web page: http://www.icpsr.umich.edu. Census Data Individual Census data used in Section 4.3 (Men 15-24 years-old, 1960-2000), and in Section 5 (Mothers 25-50 years-old, 1960-1980) are from the Integrated Public Use Microdata Series: Version $5.0(2010)$.

\section{Unilateral Divorce Coding}

The coding for unilateral divorce and separation requirements comes from Friedberg (1998) and Gruber (2004). The coding for equitable division of property is from Rasul (2004). The coding for requirements of fault regarding property division is from Mechoulan (2005). See Table 1 for details.

\section{Population Counts (for arrest rates)}

Population counts by year and state are taken from Donohue and Wolfers (2005). For counts at yearstate-age level, we use the U.S. Census Intercensal Population Data, which is available for all years starting in 1970. Data is available at the NBER website: http://www.nber.org/data/censusintercensal-population.

For population counts at the state-race-year level, we use data from the National Cancer Institute, Surveillance Epidemiology and End Results, available, starting in 1969 at http://seer.cancer.gov/popdata/download.html.

For the period 1965-1969, we make a linear interpolation using IPUMS Census data for the years 1960 and 1970. 


\section{Prisoners, and Death Penalty}

Data on number of prisoners and the existence of death penalty are from Donohue and Wolfers (2005), available at Justin Wolfers' web page:

http://bpp.wharton.upenn.edu/jwolfers/DeathPenalty.shtml. The variable indicating the stock of incarcerated people have the same states missing for the years 1965, 1968 and 1970-72.

\section{Unemployment rate and per capita Income}

The data is from the "Moffitt Benefits File", available from Robert Moffitt's web page:

http://www.econ.jhu.edu/people/moffitt/ben_data.txt.

\section{Demographic Covariates}

The fraction of people below the poverty line, fraction of blacks and the age structure of the population (5-year cohorts) are constructed from March CPS data starting in 1977. Since for previous years some states are grouped in March CPS, we make a lineal interpolation using IPUMS census data. The share of foreign-born population is also by linear interpolation of census data. 


\section{References}

Ananat, Elizabeth, and Guy Michaels. 2008. The effect of marital breakup on the income distribution of women with children. Journal of Human Resources 43(3): 611-629.

Alesina, Alberto, and Paola Giuliano. 2007. Divorce, fertility and the value of marriage. Unpublished manuscript. Harvard University.

Bedard, Kelly, and Olivier Deschênes. 2005. Sex preferences, marital dissolution, and the economic status of women. Journal of Human Resources 40(2): 411-434.

Bertrand, Marianne, Esther Duflo, and Sendhil Mullainathan. 2004. How much should we trust differences-in-differences estimates? Quarterly Journal of Economics 119 (1): 249-75.

Blau, Judith R., and Peter M. Blau. 1982. The cost of inequality: metropolitan structure and violent Crime. American Sociological Review 47(1): 114-129.

Cáceres-Delpiano, Julio, and Eugenio Giolito. 2008. How unilateral divorce affects children. Discussion paper $n^{\circ} 3342$, Institute for the Study of Labor, Bonn.

--------. 2008b. The impact of unilateral divorce on crime. Discussion paper $\mathrm{n}^{\circ} 3380$, Institute for the Study of Labor, Bonn.

Chiappori, Pierre André, Bernard Fortin, and Guy Lacroix. 2002. Marriage markets, divorce legislation, and household labor supply. Journal of Political Economy 85(6): 1141-1187.

Chilton, Roland, and Dee Weber.2000. Uniform crime reporting program data [United States]: Arrests by age, sex, and race for Police Agencies in Metropolitan Statistical Areas, 1960-1997 [Computer file]. 2nd ICPSR version. Amherst, MA: University of Massachusetts [producer]. Ann Arbor, MI: Inter-university Consortium for Political and Social Research [distributor].

Dee, Thomas S. 2003. Until death do you part: The effects of unilateral divorce on spousal homicides. Economic Inquiry 41(1): 163-182.

Donohue, John J., and Steven Levitt. 2001. The impact of legalized abortion on crime. Quarterly Journal of Economics 116(2): 379-420. 
Donohue, John J., and Steven Levitt. 2004. Further evidence that legalized abortion lowered crime: A Reply to Joyce. Journal of Human Resources 39(1): 29-49.

Donohue, John J., and Steven Levitt. 2006. Measurement error, legalized abortion, and the decline in crime: A response to Foote and Goetz (2005). University of Chicago Working Paper.

Donohue, John J., and Justin Wolfers. 2005. Uses and abuses of empirical evidence in the death penalty debate. Stanford Law Review 58:791-846.

Drewianka, Scott. 2004. Divorce law and family formation. Journal of Population Economics 21(2): 485-503.

Ellman, Ira, and Sharon Lohr. 1998. Dissolving the relationship between divorce laws and divorce rates. International Review of Law and Economics 18:341-359

Fajnzylber, Pablo, D. Lederman and N. Loayza. 2002. Inequality and violent crime. Journal of Law and Economics 45 (1): 1323-1357.

Foote, Christopher, and Christopher Goetz. 2008. The impact of legalized abortion on crime: comment. Quarterly Journal of Economics 123(1): 407-423.

Friedberg, Leora. 1998. Did unilateral divorce raise divorce rates? Evidence from panel data. American Economic Review 88(3): 608-627.

Fryer, Roland, Paul Heaton, Steven Levitt, and Kevin Murphy. 2005. Measuring the impact of crack cocaine. Working paper $\mathrm{n}^{\circ}$ 11318, National Bureau of Economic Research.

Gray, Jeffrey S. 1998. Divorce-law changes, household bargaining, and married women's labor supply. American Economic Review 88 (3): 628-642.

Gruber, Jonathan. 2004. Is making divorce easier bad for children? Journal of Labor Economics 22 (4): 799-833.

Johnson, John, and Christopher Mazingo. 2000. The economic consequences of unilateral divorce for children. Unpublished manuscript, University of Illinois Office of Research.

Joyce, Ted. 2004. Did legalized abortion lower crime? Journal of Human Resources 39(1):1-28. 
Joyce, Ted. 2009. A simple test of abortion and crime. Review of Economics and Statistics 91(1):112-123.

Kelly, Morgan. 2000. Inequality and crime. The Review of Economics and Statistics 82(4): 530-539.

Lee, Jin Young, and Gary Solon. 2011. The fragility of estimated effects of unilateral divorce laws on divorce rates. Working Paper no. 16773, National Bureau of Economic Research, Cambridge, MA.Lochner, Lance, and Enrico Moretti. 2004. The effect of education on crime: evidence from prison inmates, arrests, and self-reports. American Economic Review 94(1): 155-189.

Matouschek, Niko, and Imran Rasul. 2008. The economics of the marriage contract: theories and evidence. Journal of Law and Economics 51: 59-110.

Matsueda, Ross L, and Karen Heimer. 1987. Race, family structure, and delinquency: A test of differential association and social control theories. American Sociological Review 52(6):826-840.

Mechoulan, Stéphane. 2005 Economic theory's stance on no-fault divorce. Review of the Economics of the Household 3: 337-359.

Mechoulan, Stéphane. 2006. Divorce laws and the structure of the American family. Journal of Legal Studies 35(1): 143-174.

Page, Marianne E., and Ann Huff Stevens. 2004. The economic consequences of absent parents. Journal of Human Resources 39(1): 80-107.

Paxson, Christina, and Jane Waldfogel. 2002. Work, welfare, and child maltreatment. Journal of Labor Economics 20(3): 435-474.

Peters, H. Elizabeth. 1986. Marriage and divorce: informational constraints and private contracting. American Economic Review 76 (3): 437-454.

Rand, Alicia. 1987. Transitional life events and desistance from delinquency and crime. In From boy to man, from delinquency to crime, edited by Marvin E. Wolfgang, Terence P. Thornberry, and Robert M. Figlio. Chicago: University of Chicago Press.

Rasul, Imran. 2004. The impact of divorce laws on marriage. Unpublished manuscript. University of Chicago. 
Ruggles, Trent Alexander, Genadek, Goeken, Schroeder, and Sobek. 2010. Integrated public use microdata series: Version 5.0 [Machine-readable database]. Minneapolis: University of Minnesota.

Sampson, Robert J. 1987. Urban black violence: the effect of male joblessness and family disruption. The American Journal of Sociology 93(2): 348-382.

Sampson, Robert J., and John H. Laub. 1990. Crime and deviance over the life course: the salience of adult social bonds. American Sociological Review 55: 609-627.

Sampson, Robert J., John H. Laub, and Christopher Wimer. 2006. Does marriage reduce crime? A counterfactual approach to within-individual causal effects. Criminology 44: 465-508.

Stevenson, Betsey. 2007. The impact of divorce laws on marriage-specific capital. Journal of Labor Economics 25(1): 75-94.

-------- 2008. Divorce-law and women's labor supply. Journal of Empirical Legal Studies 5(4): 853-873.

Stevenson, Betsey, and Justin Wolfers. 2006. Bargaining in the shadow of the law: divorce laws and family distress. Quarterly Journal of Economics, 121(1): 267-288.

Wilson, William J. 1987. The truly disadvantaged: the inner city, the underclass, and public policy. Chicago: University of Chicago Press

Wolfers, Justin. 2006. Did unilateral divorce raise divorce rates? A reconciliation and new results. American Economic Review 96(5):1802-1820. 


\section{FIGURE 1}

EVOlution OF Violent AND PROPERTY CRIME RATES

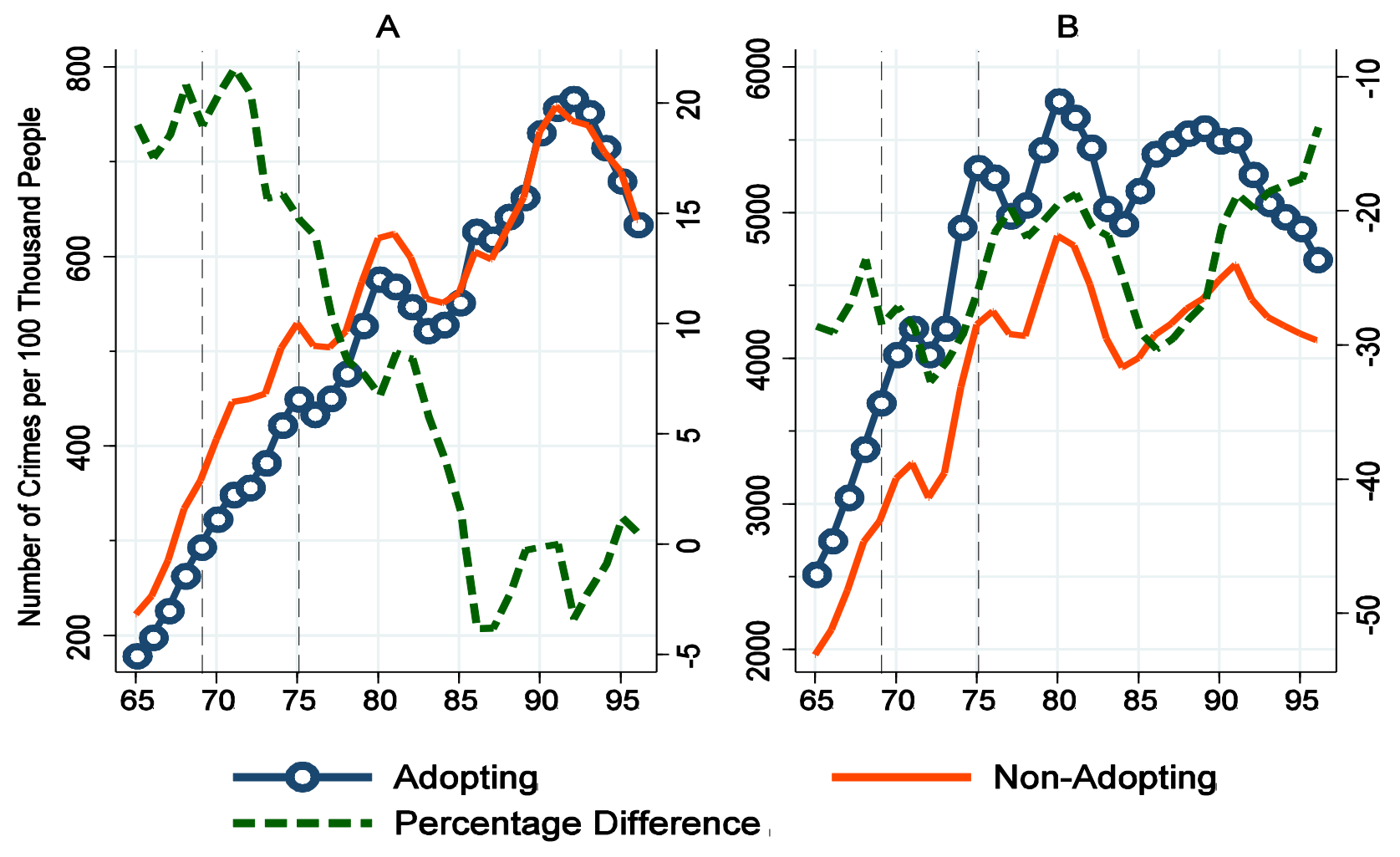

NOTE - Adopting are those States that implemented the unilateral after the year 1968.
A. Violent Crime
B. Property Crime 
FIGURE 2:

IMPACT OF UNILATERAL DiVORCE ON SELECTED CRIME RATES
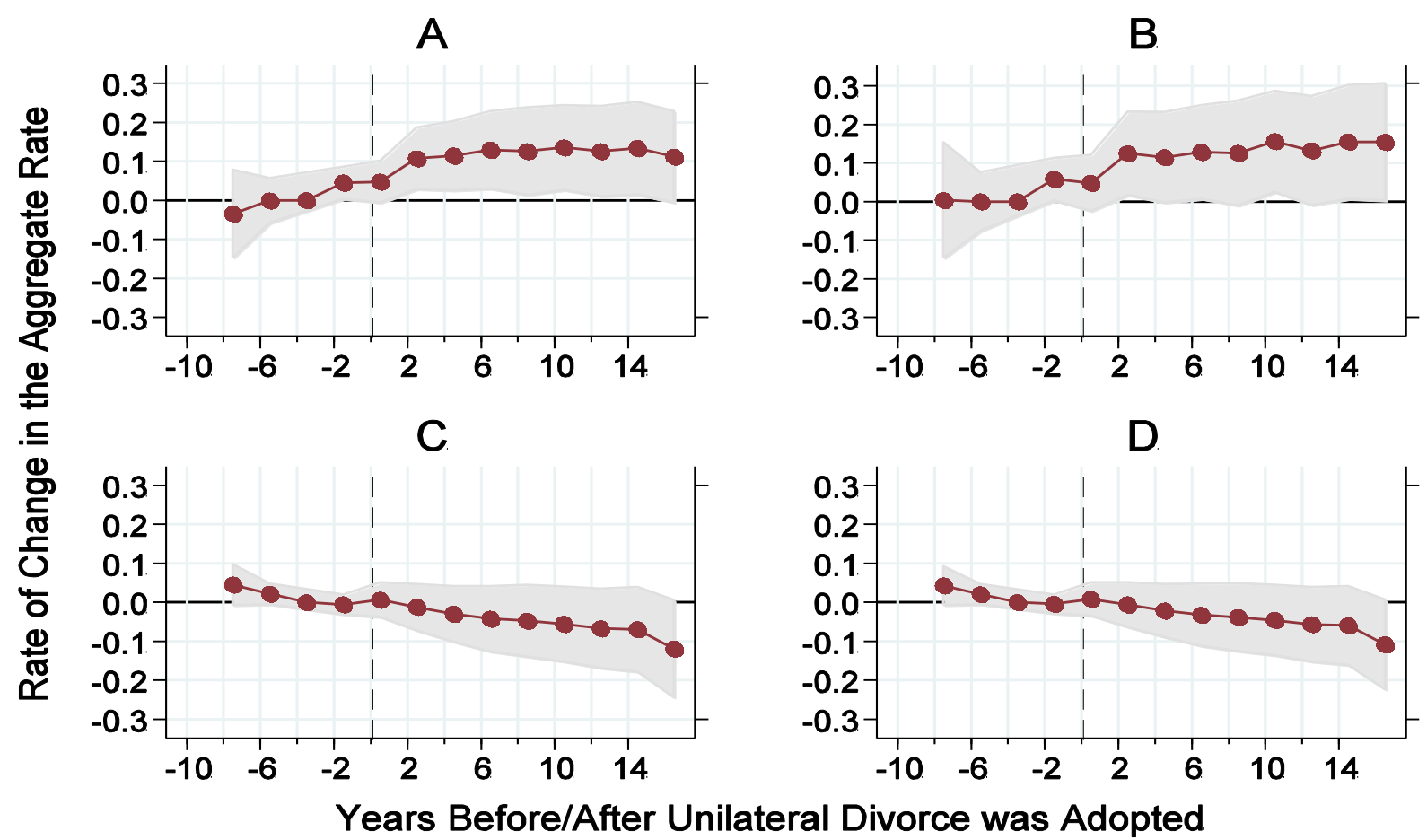

Years Before/After Unilateral Divorce was Adopted

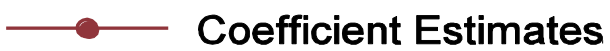

+/- 1.65 s.e.

NOTE - Each panel reports the point estimates for different regressions. Estimated coefficients refer to a dummy variables for a given state " $\mathrm{k}$ " periods before (after) the reform. The omitted category is the dummy for states three or four year before unilateral is introduced. Non-adopting states and adopting states eight or more years before the reform are grouped in the same category.

A- Violent Crime, B-Aggravated Assault, C- Property Crime, D- Total Crime 
TABlE 1: DivORCE REgUlations IN THE UNITED STATES

\begin{tabular}{|c|c|c|c|c|c|c|c|c|c|c|c|}
\hline & $\begin{array}{l}\text { Unilateral } \\
\text { Divorce }\end{array}$ & $\begin{array}{l}\text { (2) } \\
\text { Unilateral Divorce, } \\
\text { including separation } \\
\text { requirements }\end{array}$ & $\begin{array}{l}\text { (3) } \\
\text { Unilateral } \\
\text { Divorce } \\
\text { (Gruber, } \\
\text { 2004) }\end{array}$ & $\begin{array}{c}(4) \\
\text { Equitable } \\
\text { Division of } \\
\text { Property } \\
\text { and Assets }\end{array}$ & $\begin{array}{l}\text { (5) } \\
\text { No Fault for } \\
\text { Property } \\
\text { division and } \\
\text { Alimony }\end{array}$ & & $\begin{array}{c}(1) \\
\text { Unilateral } \\
\text { Divorce }\end{array}$ & $\begin{array}{c}\text { (2) } \\
\text { Unilateral Divorce, } \\
\text { including separation } \\
\text { requirements }\end{array}$ & $\begin{array}{c}(3) \\
\text { Unilateral } \\
\text { Divorce } \\
\text { (Gruber, } \\
\text { 2004) }\end{array}$ & $\begin{array}{c}\text { (4) } \\
\text { Equitable } \\
\text { Division } \\
\text { of } \\
\text { Property } \\
\text { and } \\
\text { Assets }\end{array}$ & $\begin{array}{c}\text { (5) } \\
\text { No Fault } \\
\text { for } \\
\text { Property } \\
\text { division } \\
\text { and } \\
\text { Alimony }\end{array}$ \\
\hline Alabama & 1971 & & 1971 & 1980 & Fault & Montana & 1975 & & 1973 & 1976 & 1975 \\
\hline Alaska & pre 1950 & & 1935 & pre 1950 & 1974 & Nebraska & 1972 & & 1972 & 1972 & 1972 \\
\hline Arizona & 1973 & & 1973 & pre 1950 & 1973 & $\begin{array}{l}\text { Nevada } \\
\text { New }\end{array}$ & 1973 & & 1967 & pre 1950 & 1973 \\
\hline Arkansas & & no & & 1979 & Fault & Hampshire & 1971 & & 1971 & 1988 & Fault \\
\hline California & 1970 & & 1970 & pre 1950 & 1970 & New Jersey & & 18 months, 1971 & & 1971 & 1980 \\
\hline Colorado & 1971 & & 1972 & 1972 & 1971 & New Mexico & 1973 & & 1933 & pre 1950 & 1976 \\
\hline Connecticut & 1973 & & 1973 & 1973 & Fault & New York & & no & & 1962 & Fault \\
\hline Delaware & & no & 1968 & pre 1950 & 1974 & N. Carolina & & 1 year, pre-1968 & & 1981 & Fault \\
\hline D. of Columbia & & 1 year, 1977 & & 1977 & Fault & N. Dakota & 1971 & & 1971 & pre 1950 & Fault \\
\hline Florida & 1971 & & 1971 & 1988 & 1986 & Ohio & & 1 year, 1974 & & 1990 & Fault \\
\hline Georgia & 1973 & & 1973 & 1980 & Fault & Oklahoma & $1953 *$ & & 1953 & 1975 & 1975 \\
\hline Hawaii & 1973 & & 1972 & 1955 & 1960 & Oregon & 1973 & & 1971 & 1971 & 1971 \\
\hline Idaho & 1971 & & 1971 & pre 1950 & 1990 & Pennsylvania & & 3 years, 1980 & & 1979 & Fault \\
\hline Illinois & & 2 years, 1984 & & 1977 & 1977 & Rhode Island & 1976 & & 1975 & 1979 & Fault \\
\hline Indiana & 1973 & & 1973 & 1958 & 1973 & S. Carolina & & 3 years; later 1, 1969 & & 1979 & Fault \\
\hline Iowa & 1970 & & 1970 & pre 1950 & 1972 & S. Dakota & 1985 & & 1985 & pre 1950 & Fault \\
\hline Kansas & 1969 & & 1969 & pre 1950 & 1990 & Tennessee & & no & & 1959 & Fault \\
\hline Kentucky & 1972 & & 1972 & 1972 & Fault & Texas & 1974 & & 1970 & pre 1950 & Fault \\
\hline Louisiana & & 1 year, pre-1968 & & 1978 & Fault & Utah & & 3 years, pre-1968 & 1987 & pre 1950 & 1987 \\
\hline Maine & 1973 & & 1973 & 1972 & 1985 & Vermont & & 6 months, pre- 1968 & & pre 1950 & Fault \\
\hline Maryland & & 5 years.; later 2 pre-1968 & & 1969 & Fault & Virginia & & 2 years, pre-1968 & & 1982 & Fault \\
\hline Massachusetts & 1975 & & 1975 & 1974 & Fault & Washington & 1973 & & 1973 & pre 1950 & 1973 \\
\hline Michigan & 1972 & & 1972 & 1983 & Fault & W. Virginia & & $\begin{array}{c}2 \text { years; later 1, pre- } \\
1968 \\
\text { 1-year voluntary s.r.; }\end{array}$ & & 1984 & Fault \\
\hline Minnesota & 1974 & & 1974 & 1951 & 1974 & Wisconsin & $1977 * *$ & 1977 & 1978 & 1978 & 1977 \\
\hline Mississippi & & no & & pre 1950 & Fault & Wyoming & 1977 & & 1977 & pre 1950 & Fault \\
\hline Missouri & & 2 years, 1973 & & 1974 & Fault & & & & & & \\
\hline
\end{tabular}

NOTE - Columns (1) and (2) are from Friedberg (1998). Column (3) is from Gruber (2004): Column (4) is from Rasul (2004) and Column (5) is from Ellman and Rohr (1998).

* Date of the law is from Gruber (2004). ** Not considered unilateral by Friedberg (1998), although acknowledges ambiguity. 
TABLE 2

Average Impact of Unilateral Divorce on Selected Crime Rates (Percent Change)

(1)

Basic
(2)

$(1)+$
(3)

(2) + State
(4)

(5)

Demographic

\section{A) FRIEDBERG (1998) CODING}

\begin{tabular}{|c|c|c|c|c|c|}
\hline $\begin{array}{c}\text { Total Crime Rate } \\
\{4,540 \text { per } 100,000 \text { habitants }\}\end{array}$ & $\begin{array}{l}-0.0555 \\
{[0.0422]}\end{array}$ & $\begin{array}{l}-0.0554 * \\
{[0.0324]}\end{array}$ & $\begin{array}{l}-0.0427 \\
{[0.0323]}\end{array}$ & $\begin{array}{l}-0.0383 \\
{[0.0341]}\end{array}$ & $\begin{array}{c}0.0451 \\
{[0.0280]}\end{array}$ \\
\hline $\begin{array}{c}\text { Property Crime Rate } \\
\{4,115 \text { per } 100,000 \text { habitants }\}\end{array}$ & $\begin{array}{c}-0.0637 \\
{[0.0456]}\end{array}$ & $\begin{array}{l}-0.0648 * \\
{[0.0340]}\end{array}$ & $\begin{array}{l}-0.0521 \\
{[0.0336]}\end{array}$ & $\begin{array}{l}-0.0481 \\
{[0.0354]}\end{array}$ & $\begin{array}{c}0.0401 \\
{[0.0273]}\end{array}$ \\
\hline $\begin{array}{c}\text { Violent Crime Rate } \\
\{425 \text { per } 100,000 \text { habitants }\}\end{array}$ & $\begin{array}{c}0.0964 * \\
{[0.0486]}\end{array}$ & $\begin{array}{c}0.0793^{*} \\
{[0.0415]}\end{array}$ & $\begin{array}{l}0.0880 * * \\
{[0.0405]}\end{array}$ & $\begin{array}{l}0.0959 * * \\
{[0.0454]}\end{array}$ & $\begin{array}{r}0.0941 * * \\
{[0.0438]}\end{array}$ \\
\hline \multicolumn{6}{|l|}{$\frac{\text { B) FRIEDBERG (1998), INCLUDING }}{\underline{\text { SEPARATION REQUIREMENTS) }}}$} \\
\hline Total Crime Rate & $\begin{array}{c}-0.0713 * \\
{[0.0419]}\end{array}$ & $\begin{array}{c}-0.0528 * \\
{[0.0306]}\end{array}$ & $\begin{array}{c}-0.0445 \\
{[0.0296]}\end{array}$ & $\begin{array}{c}-0.0439 \\
{[0.0295]}\end{array}$ & $\begin{array}{c}0.0345 \\
{[0.0224]}\end{array}$ \\
\hline Property Crime Rate & $\begin{array}{l}-0.0826^{*} \\
{[0.0459]}\end{array}$ & $\begin{array}{c}-0.0628^{*} \\
{[0.0329]}\end{array}$ & $\begin{array}{l}-0.0546 * \\
{[0.0315]}\end{array}$ & $\begin{array}{l}-0.0546 * \\
{[0.0312]}\end{array}$ & $\begin{array}{c}0.0307 \\
{[0.0227]}\end{array}$ \\
\hline & [0.0454] & {$[0.0353]$} & [0.0346] & {$[0.0378]$} & [0.0343] \\
\hline \multicolumn{6}{|l|}{ C) GRUBER (2004) } \\
\hline Total Crime Rate & $\begin{array}{c}-0.0487 \\
{[0.0418]}\end{array}$ & $\begin{array}{c}-0.051 \\
{[0.0319]}\end{array}$ & $\begin{array}{c}-0.0436 \\
{[0.0313]}\end{array}$ & $\begin{array}{l}-0.0407 \\
{[0.0328]}\end{array}$ & $\begin{array}{c}0.0442 * \\
{[0.0250]}\end{array}$ \\
\hline Property Crime Rate & $\begin{array}{c}-0.055 \\
{[0.0451]}\end{array}$ & $\begin{array}{c}-0.0586^{*} \\
{[0.0335]}\end{array}$ & $\begin{array}{l}-0.0512 \\
{[0.0326]}\end{array}$ & $\begin{array}{l}-0.0485 \\
{[0.0342]}\end{array}$ & $\begin{array}{c}0.0405 \\
{[0.0246]}\end{array}$ \\
\hline Violent Crime Rate & $\begin{array}{c}0.0911 * \\
{[0.0495]}\end{array}$ & $\begin{array}{l}0.0726 * \\
{[0.0419]}\end{array}$ & $\begin{array}{l}0.0794 * \\
{[0.0410]}\end{array}$ & $\begin{array}{l}0.0854^{*} \\
{[0.0435]}\end{array}$ & $\begin{array}{r}0.0835 * * \\
{[0.0396]}\end{array}$ \\
\hline Observations (1965-1996) & 1,632 & 1,632 & 1,613 & 1,613 & 1,613 \\
\hline
\end{tabular}

NOTE - All specifications include dummies by state of residence and dummies by year. Demographic variables include dummies for the fraction of blacks, fraction of immigrants, a quadratic polynomial in state population, and dummies for the state-year age structure of the population. State aggregate variables include the log of state per capita income, the state unemployment rate, dummies for the consideration of fault for property division and for the existence of norms regarding the equitable division of property in the case of divorce. Other variables include dummies for the existence of death penalty, abortion accessibility, the lagged incarcerated population and a dummy for the crack introduction in the late 80's.

Mean Crime Rate for the period under analysis in parentheses. Robust standard errors clustered by state, in brackets. $* \mathrm{p}<0.10, * * \mathrm{p}<0.05$ and $* * * \mathrm{p}<0.01$. 
TABLE 3

DyNAMic IMPACT OF Unilateral DiVORCE ON Violent CRime RATES (RATE OF Change)

\begin{tabular}{|c|c|c|c|c|c|}
\hline & $\begin{array}{c}(1) \\
\text { Basic }\end{array}$ & $\begin{array}{c}(2) \\
(1)+ \\
\text { Demographic }\end{array}$ & $\begin{array}{c}(3) \\
(2)+\text { State } \\
\text { Aggregate }\end{array}$ & $\begin{array}{c}(4) \\
(3)+\text { Policy }\end{array}$ & $\begin{array}{c}(5) \\
(4)+ \\
\text { Gruber }\end{array}$ \\
\hline First 3 years after the reform & $\begin{array}{c}0.0629 \\
{[0.0462]}\end{array}$ & $\begin{array}{c}0.0646 \\
{[0.0390]}\end{array}$ & $\begin{array}{l}0.0740 * \\
{[0.0397]}\end{array}$ & $\begin{array}{l}0.0809 * \\
{[0.0453]}\end{array}$ & $\begin{array}{c}0.0628 \\
{[0.0445]}\end{array}$ \\
\hline 4-7 years since adoption & $\begin{array}{c}0.1088 * \\
{[0.0589]}\end{array}$ & $\begin{array}{c}0.0905 \\
{[0.0564]}\end{array}$ & $\begin{array}{c}0.0921 \\
{[0.0555]}\end{array}$ & $\begin{array}{c}0.099 \\
{[0.0592]}\end{array}$ & $\begin{array}{c}0.0951 \\
{[0.0577]}\end{array}$ \\
\hline $8-11$ years since adoption & $\begin{array}{c}0.1193 * \\
{[0.0619]}\end{array}$ & $\begin{array}{l}0.0994 * \\
{[0.0563]}\end{array}$ & $\begin{array}{l}0.1085 * \\
{[0.0551]}\end{array}$ & $\begin{array}{l}0.1118 * \\
{[0.0557]}\end{array}$ & $\begin{array}{c}0.1040 * \\
{[0.0576]}\end{array}$ \\
\hline $12-15$ years since adoption & $\begin{array}{c}0.1189 * \\
{[0.0668]}\end{array}$ & $\begin{array}{c}0.1175^{*} \\
{[0.0636]}\end{array}$ & $\begin{array}{c}0.1388 * * \\
{[0.0604]}\end{array}$ & $\begin{array}{c}0.1415 * * \\
{[0.0594]}\end{array}$ & $\begin{array}{c}0.1211 * \\
{[0.0617]}\end{array}$ \\
\hline $16-20$ years since adoption & $\begin{array}{c}0.0932 \\
{[0.0681]}\end{array}$ & $\begin{array}{c}0.0863 \\
{[0.0704]}\end{array}$ & $\begin{array}{c}0.1119 \\
{[0.0680]}\end{array}$ & $\begin{array}{c}0.1145^{*} \\
{[0.0668]}\end{array}$ & $\begin{array}{c}0.0997 \\
{[0.0682]}\end{array}$ \\
\hline 20-22 years since adoption & $\begin{array}{c}0.0942 \\
{[0.0698]}\end{array}$ & $\begin{array}{c}0.0722 \\
{[0.0738]}\end{array}$ & $\begin{array}{c}0.0966 \\
{[0.0728]}\end{array}$ & $\begin{array}{c}0.1001 \\
{[0.0720]}\end{array}$ & $\begin{array}{c}0.0648 \\
{[0.0705]}\end{array}$ \\
\hline 23 years or more since adoption & $\begin{array}{c}0.1363 \\
{[0.0880]}\end{array}$ & $\begin{array}{c}0.0791 \\
{[0.0884]}\end{array}$ & $\begin{array}{c}0.105 \\
{[0.0859]}\end{array}$ & $\begin{array}{c}0.1132 \\
{[0.0868]}\end{array}$ & $\begin{array}{c}0.065 \\
{[0.0858]}\end{array}$ \\
\hline Observations (1965-1996) & 1,632 & 1,632 & 1,613 & 1,613 & 1,613 \\
\hline State Fixed Effects & $\mathrm{X}$ & $X$ & $\mathrm{X}$ & $\mathrm{X}$ & $\mathrm{X}$ \\
\hline Year Fixed Effects & $X$ & $X$ & $\mathrm{X}$ & $\mathrm{X}$ & $\mathrm{X}$ \\
\hline State Demographic Variables & & $\mathrm{X}$ & $\mathrm{X}$ & $\mathrm{X}$ & $\mathrm{X}$ \\
\hline $\begin{array}{l}\text { State Aggregate Variables } \\
\text { State Policy Variables }\end{array}$ & & & $\mathrm{X}$ & $\begin{array}{l}X \\
X\end{array}$ & $\begin{array}{l}X \\
X\end{array}$ \\
\hline
\end{tabular}

NOTE - All specifications include dummies by state of residence and dummies by year. Demographic variables include dummies for the fraction of blacks, fraction of immigrants, a quadratic polynomial in state population, and dummies for the state-year age structure of the population. State aggregate variables include the log of state per capita income, the state unemployment rate, dummies for the consideration of fault for property division and for the existence of norms regarding the equitable division of property in the case of divorce. Other variables include dummies for the existence of death penalty, abortion accessibility, the lagged incarcerated population and a dummy for the crack introduction in the late 80's. Robust standard errors clustered by state, in brackets. $* \mathrm{p}<0.10, * * \mathrm{p}<0.05$ and $* * * \mathrm{p}<0.01$. 
TABle 4: EFFeCt of Unilateral Divorce on ARrest RAtes by RACE (RATE of Change)

\begin{tabular}{|c|c|c|c|c|c|c|c|c|c|}
\hline & \multicolumn{3}{|c|}{ VIOLENT CRIME } & \multicolumn{3}{|c|}{ AgGRAVATED ASSAULT } & \multicolumn{3}{|c|}{ MURDER } \\
\hline & (1) & (2) & (3) & (4) & (5) & $(6)$ & (7) & $(8)$ & (9) \\
\hline & Total & White & Black & Total & White & Black & Total & White & Black \\
\hline \multirow{2}{*}{ First 3 years after the reform } & 0.0766 & $0.1692 * *$ & $0.1498 * *$ & 0.0981 & $0.1437 *$ & $0.1650 *$ & 0.1121 & $0.1903 * *$ & $0.3029 * *$ \\
\hline & {$[0.080]$} & {$[0.068]$} & {$[0.074]$} & {$[0.076]$} & {$[0.086]$} & {$[0.086]$} & {$[0.106]$} & {$[0.089]$} & {$[0.120]$} \\
\hline \multirow[t]{2}{*}{ 4-7 years since adoption } & $0.1376^{*}$ & $0.2403 * * *$ & $0.1860 * *$ & $0.2112 * *$ & $0.2707 * *$ & $0.2178^{*}$ & $0.2024 * *$ & $0.2688 * *$ & 0.1717 \\
\hline & [0.074] & {$[0.086]$} & {$[0.087]$} & [0.099] & [0.113] & {$[0.120]$} & [0.091] & {$[0.104]$} & {$[0.123]$} \\
\hline \multirow[t]{2}{*}{$8-11$ years since adoption } & $0.2593 * *$ & $0.3543 * * *$ & $0.2770 *$ & $0.3640 * * *$ & $0.4394 * * *$ & $0.3551 *$ & $0.3400 * *$ & $0.2440^{*}$ & $0.3238 * *$ \\
\hline & {$[0.101]$} & {$[0.116]$} & {$[0.140]$} & {$[0.120]$} & {$[0.142]$} & {$[0.188]$} & {$[0.128]$} & {$[0.139]$} & {$[0.131]$} \\
\hline \multirow[t]{2}{*}{ 12-15 years since adoption } & $0.2677 * *$ & $0.3728 * * *$ & $0.2408 * *$ & $0.3522 * * *$ & $0.4544 * *$ & $0.2884^{*}$ & $0.4356 * *$ & $0.3201 * *$ & $0.4734 * *$ \\
\hline & {$[0.106]$} & {$[0.125]$} & {$[0.116]$} & {$[0.126]$} & {$[0.170]$} & {$[0.163]$} & {$[0.171]$} & {$[0.135]$} & {$[0.210]$} \\
\hline \multirow{2}{*}{ 16-20 years since adoption } & 0.195 & $0.3755^{* * *}$ & 0.1966 & $0.3410 * *$ & $0.5064 * * *$ & $0.3330 * *$ & 0.2412 & 0.1939 & 0.3362 \\
\hline & {$[0.118]$} & [0.127] & {$[0.123]$} & {$[0.135]$} & [0.178] & [0.160] & {$[0.220]$} & [0.127] & {$[0.272]$} \\
\hline \multirow[t]{2}{*}{ 20-22 years since adoption } & 0.2277 & $0.4181 * * *$ & $0.2208^{*}$ & $0.3789 * *$ & $0.5634 * * *$ & $0.3339 * *$ & 0.2193 & 0.2264 & 0.3352 \\
\hline & [0.144] & {$[0.142]$} & {$[0.115]$} & {$[0.158]$} & {$[0.194]$} & {$[0.160]$} & [0.229] & [0.137] & {$[0.286]$} \\
\hline \multirow[t]{2}{*}{23 years or more since adoption } & 0.1436 & 0.2255 & 0.1098 & 0.2703 & $0.3608^{*}$ & 0.2205 & 0.1972 & 0.0829 & 0.0769 \\
\hline & [0.159] & {$[0.154]$} & [0.135] & {$[0.177]$} & {$[0.198]$} & [0.171] & {$[0.228]$} & [0.146] & {$[0.273]$} \\
\hline $\begin{array}{l}\text { Average Impact of Unilateral Divorce } \\
\text { (1965-97) }\end{array}$ & $\begin{array}{c}0.1848 * * * \\
{[0.065]}\end{array}$ & $\begin{array}{c}0.2887 * * * \\
{[0.073]}\end{array}$ & $\begin{array}{c}0.2326 * * * \\
{[0.082]}\end{array}$ & $\begin{array}{l}0.2483 * * * \\
{[0.080]}\end{array}$ & $\begin{array}{c}0.3193 * * * \\
{[0.101]}\end{array}$ & $\begin{array}{c}0.2620 * * \\
{[0.109]}\end{array}$ & $\begin{array}{c}0.2354 * * \\
{[0.097]}\end{array}$ & $\begin{array}{c}0.2663 * * * \\
{[0.089]}\end{array}$ & $\begin{array}{c}0.3100 * * \\
{[0.132]}\end{array}$ \\
\hline Observations & 1,664 & 1,664 & 1,664 & 1,664 & 1,664 & 1,664 & 1,664 & 1,664 & 1,664 \\
\hline
\end{tabular}

NOTE - Dependent variable is crime rate by age per 100,000 people of the age group in a given state and year. Coefficients represent the rate of change in crime rates for the different cohorts affected by the reform. This elasticity is calculated using the sample mean as the base. All specifications include dummies by state of residence and dummies by year, dummies for the fraction of blacks, fraction of immigrants, dummies for the state-year age structure of the population, a quadratic polynomial in state population, the log of state per capita income, the state unemployment rate, dummies for the consideration of fault for property division and for the existence of norms regarding the equitable division of property in the case of divorce, dummies for the existence of death penalty, abortion accessibility, the lagged incarcerated population and a dummy for the crack introduction in the late 80 's.

Robust standard errors clustered by state, in brackets. $* \mathrm{p}<0.10, * * \mathrm{p}<0.05$ and $* * * \mathrm{p}<0.01$. 
TABLE 5

EfFect of Unilateral Divorce on Age-Specific Violent ArRest Rates. (RAte of Change)

(1)

(2)

(3)

(4)

(5)

Friedberg

(1998),

Demographic

variables only
(1) + Aggregate variables
(2) + Policy variables
Interactions including Sep. Requirements.

$\begin{array}{lccccc}\text { Born 6+ years after the reform } & -0.1946 & -0.1552 & -0.0832 & -0.1365 & 0.1682 \\ & {[0.166]} & {[0.162]} & {[0.162]} & {[0.195]} & {[0.160]} \\ \text { Born 1-5 years after the reform } & -0.0223 & 0.012 & 0.068 & -0.0511 & 0.2083^{*} \\ & {[0.155]} & {[0.140]} & {[0.138]} & {[0.167]} & {[0.108]} \\ & 0.0676 & 0.0993 & 0.1487 & 0.0259 & 0.3013^{* *} \\ \text { Age 0-3 when the reform } & {[0.111]} & {[0.102]} & {[0.103]} & {[0.113]} & {[0.122]} \\ & 0.0832 & 0.1141 & 0.1577^{*} & 0.0608 & 0.2287^{* * *} \\ \text { Age 4-7 when the reform } & {[0.079]} & {[0.084]} & {[0.085]} & {[0.077]} & {[0.073]} \\ & 0.1109 & 0.1381^{*} & 0.1760^{* *} & 0.0988^{*} & 0.2208^{* * *} \\ \text { Age 8-11 when the reform } & {[0.073]} & {[0.079]} & {[0.079]} & {[0.054]} & {[0.043]} \\ & 0.1057^{*} & 0.1253^{*} & 0.1607^{* *} & 0.1339^{* * *} & 0.2841^{* * *} \\ \text { Age 12-15 when the reform } & {[0.062]} & {[0.063]} & {[0.066]} & {[0.021]} & {[0.026]} \\ & 0.0747 & 0.0852 & 0.1229^{* *} & 0.1242^{* * *} & 0.2376^{* * *} \\ \text { Age 16-more when the reform } & {[0.054]} & {[0.052]} & {[0.061]} & {[0.005]} & {[0.007]} \\ & & & & & 16,830 \\ \\ \text { Observations } & 16,830 & 16,640 & 16,640 & 16,830 \\ & & & & & \\ \text { State Demographic Variables } & \mathrm{X} & \mathrm{X} & \mathrm{X} & & \mathrm{X} \\ \text { State Aggregate Variables } & & \mathrm{X} & \mathrm{X} & & \mathrm{X} \\ \text { State Policy Variables } & \mathrm{X} & \mathrm{X} & \mathrm{X} & \mathrm{X} & \\ \text { Age*year interactions } & & & & \mathrm{X} & \\ \text { State*age interactions } & & & & & \mathrm{X} \\ \text { State*year interactions } & & & & & \end{array}$

NOTE - Dependent variable is violent arrest rate by age per 100,000 people of the age group in a given state and year. Coefficients represent the rate of change in crime rates for the different cohorts affected by the reform. This elasticity is calculated using the sample mean as the base. All specifications include state, year and age fixed effects. Demographic variables include dummies for the fraction of blacks, fraction of immigrants, a quadratic polynomial in state population, and dummies for the state-year age structure. State aggregate variables include the log of state per capita income, the state unemployment rate, dummies for the requirement of fault for property division, and dummies for the existence of norms regarding the equitable division of property in the case of divorce. Other variables include dummies for the existence of death penalty, abortion accessibility and early legalizing states, and a dummy for the crack introduction in the late 80's.

Robust standard errors clustered by state, in brackets. $* \mathrm{p}<0.10,{ }^{* *} \mathrm{p}<0.05$ and $* * * \mathrm{p}<0.01$. 
(1)

Demographic
variables only
(2) (3)

(3)

(4)

(5)

Friedberg (1998), including Sep. Requirements

\begin{tabular}{|c|c|c|c|c|c|}
\hline \multirow[t]{2}{*}{ Born $6+$ years after the reform } & -0.1148 & -0.0157 & 0.022 & -0.2268 & 0.3254 \\
\hline & {$[0.166]$} & {$[0.160]$} & {$[0.167]$} & {$[0.340]$} & {$[0.217]$} \\
\hline \multirow[t]{2}{*}{ Born $1-5$ years after the reform } & 0.0993 & 0.2297 & $0.2644^{*}$ & -0.0305 & $0.4400 * *$ \\
\hline & {$[0.178]$} & {$[0.152]$} & {$[0.153]$} & [0.302] & {$[0.174]$} \\
\hline \multirow[t]{2}{*}{ Age $0-3$ when the reform } & 0.1701 & $0.2990 * *$ & $0.3338 * *$ & 0.12 & $0.5644 * *$ \\
\hline & {$[0.147]$} & {$[0.131]$} & [0.134] & [0.207] & {$[0.231]$} \\
\hline \multirow[t]{2}{*}{ Age $4-7$ when the reform } & $0.1589 *$ & $0.2682 * * *$ & $0.2999 * * *$ & 0.1752 & $0.4450 * * *$ \\
\hline & {$[0.094]$} & [0.099] & [0.103] & {$[0.122]$} & {$[0.154]$} \\
\hline \multirow[t]{2}{*}{ Age $8-11$ when the reform } & $0.2158 * *$ & $0.2807 * * *$ & $0.3050 * * *$ & $0.2327 * * *$ & $0.3699 * * *$ \\
\hline & {$[0.089]$} & [0.097] & {$[0.100]$} & {$[0.072]$} & {$[0.067]$} \\
\hline \multirow[t]{2}{*}{ Age $12-15$ when the reform } & $0.1976^{* *}$ & $0.2220 * *$ & $0.2370^{* *}$ & $0.2396^{* * *}$ & $0.3521 * * *$ \\
\hline & {$[0.087]$} & {$[0.086]$} & [0.092] & {$[0.026]$} & {$[0.039]$} \\
\hline \multirow[t]{2}{*}{ Age 16-more when the reform } & 0.1075 & 0.1066 & 0.1168 & $0.2140 * * *$ & $0.2745^{* * *}$ \\
\hline & {$[0.075]$} & {$[0.068]$} & [0.081] & [0.007] & {$[0.010]$} \\
\hline State Demographic Variables & $X$ & $X$ & $\mathrm{X}$ & & \\
\hline State Aggregate Variables & & $\mathrm{X}$ & $\mathrm{X}$ & & \\
\hline State Policy Variables & & & $\mathrm{X}$ & & \\
\hline Age* year interactions & $X$ & $\mathrm{X}$ & $\mathrm{X}$ & $\mathrm{X}$ & $\mathrm{X}$ \\
\hline State*age interactions & & & & $X$ & $X$ \\
\hline State*year interactions & & & & $X$ & $X$ \\
\hline Observations & 16,830 & 16,640 & 16,640 & 16,830 & 16,830 \\
\hline
\end{tabular}

NOTE - Dependent variable is violent arrest rate by age per 100,000 people of the age group in a given state and year. Coefficients represent the rate of change in crime rates for the different cohorts affected by the reform. This elasticity is calculated using the sample mean as the base. All specifications include state, year and age fixed effects. Demographic variables include dummies for the fraction of blacks, fraction of immigrants, a quadratic polynomial in state population, and dummies for the state-year age structure. State aggregate variables include the log of state per capita income, the state unemployment rate, dummies for the requirement of fault for property division, and dummies for the existence of norms regarding the equitable division of property in the case of divorce. Other variables include dummies for the existence of death penalty, abortion accessibility and early legalizing states, and a dummy for the crack introduction in the late 80's.

Robust standard errors clustered by state, in brackets. $* \mathrm{p}<0.10, * * \mathrm{p}<0.05$ and $* * * \mathrm{p}<0.01$. 


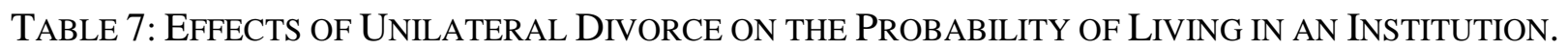

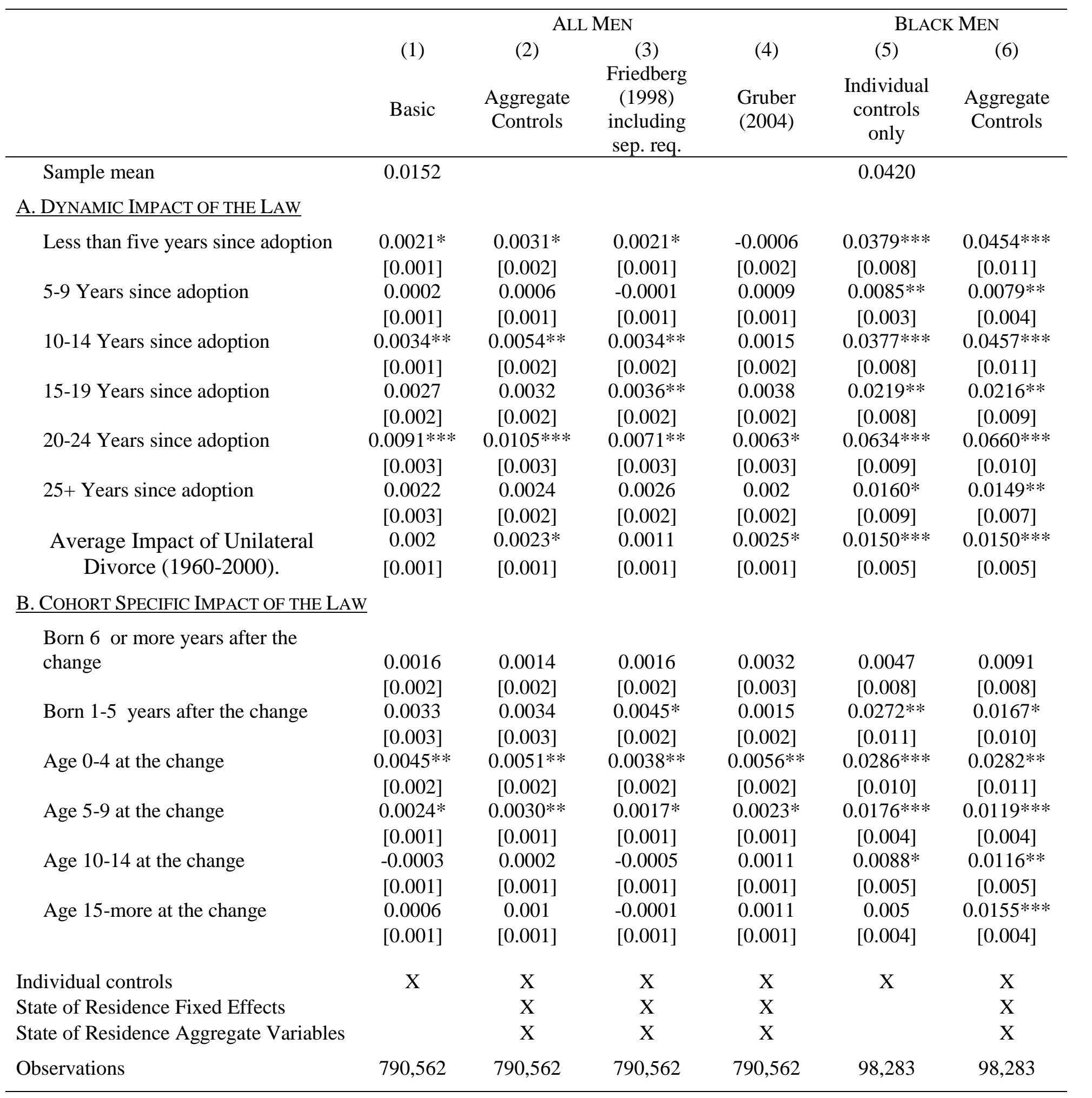

NOTE- All Specifications include state of birth, year, age and race fixed effects, race*year and age*year interactions. State Aggregate variables include the log of personal income per capita, the unemployment rate, fractions of blacks, age composition of the population, dummies for equitable division of property upon divorce and the consideration of fault in property division. Other variables include dummies for the existence of death penalty and abortion accessibility at the year of birth. Robust standard errors clustered by state of birth. $* \mathrm{p}<0.10, * * \mathrm{p}<0.05$ and $* * * \mathrm{p}<0.01$. 
TABLE 8

EFFeCtS OF Unilateral DivorCe ON MOTHER'S OUTCOMES. US CENSUS 1960-1980.

\begin{tabular}{cccc}
\hline & $(1)$ & $(2)$ & $(3)$ \\
& All & HS or Less & At Least Some college \\
\hline CURRENTLY DIVORCED & $0.0091 * *$ & & \\
\% Change & {$[0.002]$} & $0.0099 * * *$ & $0.0069^{* * *}$ \\
HOUSEHOLD HEAD & $\{0.0489\}$ & {$[0.002]$} & {$[0.002]$} \\
& $18.61 \%$ & $\{0.0472\}$ & $\{0.0556\}$ \\
\% Change & $0.0067 * *$ & $20.97 \%$ & $12.41 \%$ \\
& {$[0.003]$} & $0.0068 * *$ & 0.0043 \\
REAL FAMILY INCOME $(L O G)$ & $\{0.0993\}$ & {$[0.003]$} & {$[0.003]$} \\
& $7.15 \%$ & $\{0.1013\}$ & $5.02 \%$ \\
& & $7.11 \%$ & \\
\% Change & $-0.0220 *$ & & -0.0036 \\
& {$[0.013]$} & -0.0232 & {$[0.011]$} \\
Observations & $0.0169 * *$ & {$[0.014]$} & 0.0043 \\
& {$[0.007]$} & $0.0184 * *$ & {$[0.003]$} \\
& $\{0.3091\}$ & {$[0.008]$} & $\{0.1741\}$ \\
& $6.02 \%$ & $\{0.3439\}$ & $2.93 \%$ \\
& $1,589,456$ & $5.73 \%$ & 459,673 \\
\hline
\end{tabular}

NOTE - Sample means between curly brackets. All Specifications include state of residence, year, age of the mother, age of the youngest child, race and education fixed effects, age*year and education*year interactions. Other covariates are the log of personal income per capita, the unemployment rate, the age composition of the population, dummies for equitable division of property upon divorce, and the consideration of fault in property division.

Robust standard errors clustered by state of birth. * $\mathrm{p}<0.10$, ** $\mathrm{p}<0.05$ and $* * * \mathrm{p}<0.01$. 
TABLE 9

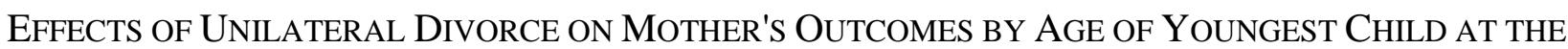
TIME OF THE REFORM. US CENSUS 1960-1980.

\begin{tabular}{|c|c|c|c|c|}
\hline & $\begin{array}{c}(1) \\
\text { CURRENTLY } \\
\text { DIVORCED }\end{array}$ & $\begin{array}{c}(2) \\
\text { HEAD OF } \\
\text { HOUSEHOLD }\end{array}$ & $\begin{array}{c}(3) \\
\text { REAL FAMILY } \\
\text { INCOME (LOG) }\end{array}$ & $\begin{array}{c}(4) \\
\text { BELOW } \\
\text { POVERTY }\end{array}$ \\
\hline Born $6+$ years after the Reform & $\begin{array}{c}-0.0258 * * * \\
{[0.008]}\end{array}$ & $\begin{array}{c}-0.0248 * * * \\
{[0.006]}\end{array}$ & $\begin{array}{c}0.0114 \\
{[0.015]}\end{array}$ & $\begin{array}{r}-0.0057 \\
{[0.009]}\end{array}$ \\
\hline Born 1-5 years after the Reform & $\begin{array}{l}-0.0001 \\
{[0.004]}\end{array}$ & $\begin{array}{r}-0.0013 \\
{[0.004]}\end{array}$ & $\begin{array}{l}-0.0188 \\
{[0.013]}\end{array}$ & $\begin{array}{c}0.0129 * \\
{[0.007]}\end{array}$ \\
\hline Age 0-4 when the reform & $\begin{array}{c}0.0153 * * * \\
{[0.003]}\end{array}$ & $\begin{array}{c}0.0142 * * * \\
{[0.003]}\end{array}$ & $\begin{array}{c}-0.0368 * * * \\
{[0.011]}\end{array}$ & $\begin{array}{c}0.0206 * * * \\
{[0.006]}\end{array}$ \\
\hline Age 5-9 when the reform & $\begin{array}{c}0.0162 * * * \\
{[0.003]}\end{array}$ & $\begin{array}{c}0.0126^{* * *} \\
{[0.003]}\end{array}$ & $\begin{array}{c}-0.0245^{* * *} \\
{[0.009]}\end{array}$ & $\begin{array}{c}0.0224 * * * \\
{[0.005]}\end{array}$ \\
\hline Age 10-more when the reform & $\begin{array}{c}0.0107 * * * \\
{[0.002]}\end{array}$ & $\begin{array}{c}0.0037 \\
{[0.003]}\end{array}$ & $\begin{array}{c}-0.0189 * \\
{[0.009]}\end{array}$ & $\begin{array}{c}0.0242 * * * \\
{[0.005]}\end{array}$ \\
\hline Observations & $1,589,456$ & $1,589,456$ & $1,575,182$ & $1,589,456$ \\
\hline
\end{tabular}

NOTE - All Specifications include state of residence, year, age of the mom, age of the youngest child, race and education fixed effects, age*year, race*year and education*year interactions. Other covariates are the $\log$ of personal income per capita, the unemployment rate, and age composition of the population. We also include dummies for equitable division of property upon divorce, and the consideration of fault in property division.

Robust standard errors clustered by state of residence. $* \mathrm{p}<0.10, * * \mathrm{p}<0.05$ and $* * * \mathrm{p}<0.01$. 